\title{
Analisis Laju Perpindahan Panas pada Baterai Ion Lithium 18650 terhadap Beban Keluarannya dengan Metode Numerik
}

\author{
A. Kurniawan \\ Departemen Teknik Mesin dan Industri, Fakultas Teknik, Universitas Gadjah Mada. \\ Jl. Grafika No. 2, Kompleks UGM, Yogyakarta 55281, Indonesia \\ e-mail: wawan.achmadkurniawan@gmail.com
}

\begin{abstract}
Abstrak
Baterai ion lithium merupakan salah satu teknologi yang sering diaplikasikan karena kelebihannya yang bisa diisi ulang. Namun dengan kelebihannya yang dapat diisi ulang, baterai ion lithium mempunyai kelemahan pada pengaturan temperaturnya, di mana sering terjadi overheating. Pada penelitian ini, penulis melakukan analisis laju perpindahan panas pada baterai ion lithium terhadap beban keluarannya dengan tujuan untuk menemukan profil temperatur baterai ketika beroperasi. Dengan simulasi numerik, penelitian ini juga bertujuan mendapatkan metode simulasi numerik yang tepat terhadap panas di baterai ion lithium. Penulis melakukan penelitian ini dengan melakukan eksperimen terhadap 1 sel baterai 18650 yang divariasikan outputnya, dilanjutkan dengan melakukan simulasi numerik dengan software ANSYS Fluent. Dari data eksperimen, didapatkan kenaikan suhu maksimum terjadi pada beban keluaran $0.4 \mathrm{ohm}$, dengan suhu maksimal $325.8 \mathrm{~K}$. Dapat disimpulkan bahwa besar keluaran dari baterai sangat mempengaruhi performa perpindahan panas baterai, semakin besar arus keluaran yang keluar baterai, semakin tinggi panas di dalam baterai. Dari penelitian ini, didapat kesimpulan bahwa laju perpindahan panas akan meningkat secara polynomial terhadap arus keluaran baterai. Simulasi laju panas baterai dengan software ANSYS Fluent menghasilkan nilai sangat mendekati dengan eksperimennya dengan nilai error $<7 \%$, sehingga metode ini cukup bisa mencerminkan fenomena panas pada baterai pada praktek sesungguhnya.
\end{abstract}

Kata kunci : baterai, lithium, perpindahan panas, numerik.

\begin{abstract}
Lithium-ion batteries are a technology that is often used because the battery can be recharged. However, with the advantages that can be recharged, lithium-ion batteries have a lack of temperature regulation, where frequent overheating occurs. In this study, the authors analyzed the effect of heat transfer on a lithium battery on its output load and found the distance between batteries against their heat generation. The author conducted this research by experimenting with 1 battery cell Lithium ion 18650 whose output was varied, then followed by doing numerical simulations with the ANSYS Fluent software. From these simulations, the authors take the heat generation profile on the battery and recalculate it with a 13-cell battery circuit with varied its distance between batteries. From the experimental data, heat generation and conduction data are obtained which are distributed on the battery. From this study, it was concluded that the heat produced by batteries is mostly produced by Joule heating on batteries.
\end{abstract}


The heat distribution in the battery is centralized in the center of the battery and doing conduction throughout the body of the battery. Convection from the battery will increase temperature of the batteries. The distance between the batteries will decrease about $0.3 \mathrm{~K}$ per 1 mm distance. ANSYS Fluent simulation produces similar data from experiment with error value less than $7 \%$, so this numerical method can reflect heat phenomenon of the battery heating.

\section{Keywords : : lithium battery, heat transfer, numerical method.}

\section{PENDAHULUAN}

Dewasa ini, kemajuan dan persaingan teknologi di bidang energi cukup pesat dikarenakan kebutuhan penduduk dunia akan energi sebanyak-banyaknya. Di bidang industri, tengah dikembangkan berbagai macam alternatif pembangkitan energi, distribusi energi, hingga penyimpanan energi untuk memperoleh hasil yang maksimal. Pada bidang penyimpanan energi, baterai ion lithium merupakan salah satu teknologi yang sering dipakai untuk peralatan elektronik hingga kendaraan listrik. Baterai ion lithium ini memiliki kelebihan untuk melakukan pengisian ulang yang cukup cepat, tidak seperti baterai pada umumnya. Namun dengan kelebihannya yang dapat diisi ulang, baterai ion lithium mempunyai kelemahan pada pengaturan temperaturnya khususnya ketika baterai tersebut telah beroperasi cukup lama. Sudah terdapat beberapa insiden overheating pada baterai yang terjadi dan mengakibatkan kerugian asset perusahaan dan personilnya.

Panas pada baterai lithium terjadi dikarenakan proses electrochemical dan joule heating yang terjadi ketika beroperasi. Joule heating merupakan sebuah proses ketika arus listrik melewati sebuah konduktor yang menyebabkan konduktor tersebut memproduksi panas (Angelo Onorati, 2009). Pada penelitian terhadap baterai lithium yang dilakukan oleh Yoshiasu Saito (2012), didapatkan hubungan antara keadaan charge batterai - State of Charge (SOC) dengan Voltase dan Power yang dikeluarkan oleh baterai lithium, dimana semakin besar SOC baterai, maka semakin besar pula voltase yang dikeluarkan oleh baterai. Namun, berbeda dengan output power yang dikeluarkan baterai, semakin tinggi SOC nya maka power yang dikeluarkan semakin besar. Pada penelitian yang dilakukan oleh Yangqing Lai (2015) didapatkan hubungan antara perubahan temperatur yang terjadi pada baterai dengan DOD (Deep of Discharge) pada baterai. Penelitian ini dilakukan dengan baterai yang sudah tersimpan lama, sehingga bisa dikatakan sudah mengalami penurunan kualitas. Namun, secara umum dapat dikatakan bahwa baterai yang tersimpan lama tidak berpengaruh besar terhadap panas yang dihasilkan oleh baterai. Zenpo Wang (2017) melakukan simulasi persebaran disipasi panas pada baterai lithium ion dengan menggunakan metode numerik pada software ANSYS Fluent. Penelitian tersebut mendapatkan hasil bahwa semakin besar aliran angin pada rangkaian baterai, pendinginan baterai semakin baik. Namun, setelah melewati kecepatan tertentu, aliran angin tidak dapat menurunkan temperatur secara maksimum. Penurunan temperatur dengan aliran angin dapat lebih baik jika antar baterai diberikan jarak tertentu.

Pada penelitian ini, penulis lebih memfokuskan pengaruh beban keluaran baterai terhadap pembangkitan panas pada baterai. Dengan mengetahui pengaruh tersebut, profil temperatur laju panas pada baterai dapat dibuat. Data tersebut akan dimasukan ke dalam sebuah simulasi, sehingga bisa didapatkan metode simulasi yang tepat untuk menggambarkan laju panas pada baterai ketika beroperasi.

Tujuan dari penelitian ini adalah untuk menemukan laju perpindahan panas pada baterai ion lithium, sehingga pada aplikasinya para praktisi dan akademisi bisa mengetahui informasi 
lebih lengkap terkait keselematan dan sistem operasi baterai ion lithium. Juga dengan simulasi numerik yang tepat terhadap laju panas baterai, maka akan mempermudah penelitian lebih lanjut terhadap baterai ion lithium baik dari sisi teknologi keselamatan maupun optimasi operasinya.

\section{METODE PENELITIAN}

Pada penelitian ini, penulis akan melakukan eksperimentasi dengan baterai lithium ion (tipe 18650) untuk mengetahui profil panas yang dihasilkan. Penulis akan mencoba mengetahui profil perpindahan panas pada baterai menggunakan eksperimen dan jurnal referensi sehingga dapat menentukan hubungan antara temperatur baterai dengan arus keluaran dan beban keluaran.

Peralatan dan bahan yang disiapkan pada penelitian ini antara lain adalah:

1. Multitester 2 buah untuk mengukur arus dan voltase secara bersamaan,

2. Coil sebagai beban keluaran sebesar $1.5 \mathrm{ohm}, 1 \mathrm{ohm}, 0.8 \mathrm{ohm}, 0.7 \mathrm{ohm}$ dan $0.4 \mathrm{ohm}$ dan kabel penghubungnya

3. Infrared Camera untuk pengukuran temperatur pada baterai

4. Computer dan software simulasi ANSYS Fluent untuk melakukan simulasi dengan metode numerik

Penulis melakukan eksperimen terhadap 1 sel baterai 18650 dengan beberapa varian outputnya, sehingga ditemukan korelasi antara suhu, arus keluaran dan waktu operasi terhadap beban keluarannya. Dari hasil tersebut penulis akan membuat sebuah grafik korelasi dan analisa distribusi panas dari tangkapan Infra Red (IR) Camera. Penulis akan membuat sebuah rangkaian sederhana untuk melakukan pengukuran terhadap satu sel baterai dan coil dengan skema berikut:

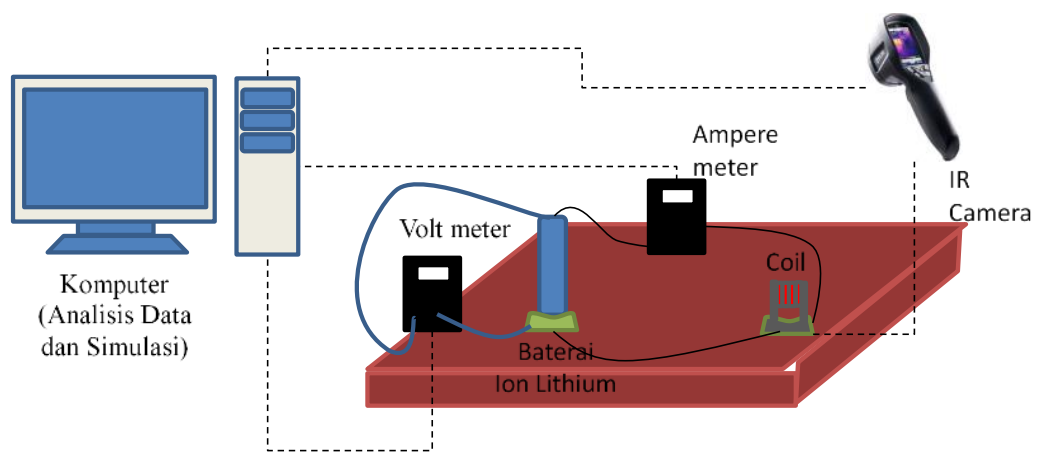

Gambar 1. Skematik Rangkaian Baterai

Pada Gambar 1, terdapat 2 multitester yang dipasang secara bersamaan agar dapat menghitung voltase pada baterai, dan arus dalam rangkaian dalam 1 waktu. Dengan variasi dari $0.4-1.5 \mathrm{ohm}$ resistansi dari coil yang telah dibuat, penulis akan mencatat voltase dan arus pada tiap percobaan yang dilakukan, lalu mengukuru temperatur baterai dengan IR camera setiap 5 menit.

Pada baterai ion lithium, fenomena yang sama dilakukan untuk mengalirkan listrik, namun terletak perbedaan pada elektroda (katoda dan anoda) di dalamnya. Katoda dan anoda pada baterai lithium sama-sama memiliki kandungan lithium di dalamnya, berbeda dengan baterai biasa. Hal tersebut dibuat sehingga memungkinkan ion lithium yang berada di katoda dan anoda dapat berpindah-pindah secara reversible. Ketika diberikan aliran listrik, elektron akan terkumpul ke anoda, sehingga membuat ion lithium juga ikut berpindah ke anoda. Kondisi ion 
lithium berpindah ke anoda ini biasanya terjadi ketika baterai dalam kondisi charge. Ketika baterai lithium tersambung dengan sebuah keluaran (output), seperti lampu, coil dan lainnya, ion lithium dan elektron pada anoda melakukan merupakan perpindahan ke katoda. Kondisi pada saat ion berpindah dari anoda ke katoda terjadi ketika baterai dalam kondisi discharge.

Komponen utama pada baterai lithium ion adalah anoda, katoda, elektrolit dan Seperti pada baterai lainnya, sistem operasi baterai memakai sistem elektrokimia, di mana listrik terjadi karena pelepasan elektron dari anoda sebagai sumbu negatif yang mengumpulkan ion muatan negatif, ke katoda yang merupakan pengumpul ion positif. Elektron yang keluar dari anoda menuju katoda baterai keluar melewati kabel yang tersambung pada baterai sehingga dapat mengalirkan listrik.

Fenomena perpindahan panas yang terjadi pada baterai terjadi secara konduksi dan konveksi. Konduksi terjadi pada panas di dalam baterai, sedangkan konveksi dilakukan oleh baterai ketika tersentuh dengan udara. Konduksi adalah perpindahan kalor tanpa diikuti oleh perpindahan partikel di dalamnya, sedangkan konveksi adalah perpindahan kalor melalui aliran yang partikel di dalamnya ikut berpindah.

Menurut hukum Fourier (Holman, 2010), besar konduksi dapat dirumuskan dalam formula:

$$
Q=-k A \frac{d T}{d x}
$$

Dari referensi penulis, didapatkan nilai konduktivitas thermal pada baterai ion lithium. Nilai konduktivitas $1.035 \mathrm{~W} / \mathrm{m} . \mathrm{K}$ (Chen, 2004) penulis pakai untuk perhitungan panas konduksi di dalam baterai.

Panas pada baterai lithium terjadi karena Joule heating dan panas reaksi entropi baterai, di mana disebabkan oleh adanya perpindahan elektron dari baterai yang melewati baterai yang memiliki internal resistansi dan terjadi reaksi kimia di dalamnya, namun diperlukan data open circuit baterai dan baterai, di mana data setiap baterai berbeda-beda. Sehingga penulis memakai persamaan yang dipakai Onorati (2009) untuk menghitung perpindahan panas di mana perumusannya adala sebagai berikut:

$$
\text { m. } C p \cdot \frac{d T}{d t}=Q-h A\left(T_{s}-T_{\infty}\right)
$$

Dan dapat disimpulkan sebagai berikut:

$$
Q=m \cdot C p \cdot \frac{d T}{d t}+h A\left(T_{s}-T_{\infty}\right)
$$

Dalam persamaan (3) ini, generasi yang terjadi dalam baterai dikeluarkan dengan konduksi ke permukaan baterai, dan melakukan konveksi ketika sudah menyentuh udara. Konduksi dihitung dengan perumusan pemanasan bahan, sedangkan konveksi dihitung dengan perumusan konveksi . Pada penelitian ini, konveksi terjadi secara natural sehingga diperlukan langkah untuk mencari nilai $h$ dengan perhitungan sebagai berikut:

$$
h=\frac{N u \cdot k}{L c}
$$


$h$ merupakan koefisien konveksi $\left(\mathrm{W} / \mathrm{m}^{2} \mathrm{~K}\right)$, Nu adalah bilangan nusselt number, $k$ merupakan nilai konduksi udara, diambil dari Table udara 1 atm (Cengel, 2008), dan Lc merupakan panjang karakteristik dari baterai. Dalam hal ini, diameter dari baterai yang menjadi panjang karakteristik yang mengeluarkan konveksi natural. Nusselt number sendiri sebenarnya merupakan sebuah rasio konveksi dan konduksi dalam sebuah fenomena perpindahan panas. Untuk mengetahui nilai Nusselt number, diperlukan penulis memakai perhitungan sebagai berikut:

$$
N u=\left\{0,825+\frac{0,387 R a^{1 / 6}}{1+\left[\left(\frac{0,492}{P r}\right)^{9 / 16}\right]^{8 / 27}}\right\}^{2}
$$

Di mana perhitungan nusselt bergantung pada nilai Rayleigh Number. Nilai Rayleigh sendiri sangat berhubungan dengan Grashoff number di mana nilai tersebut menggambarkan perilaku buoyancy dan viscocity fluida ketika memiliki massa jenis yang beragam, di mana biasanya dialami oleh fluida yang terkena perbedaan temperatur. Nilai Rayleigh diambil oleh nilai Prandtl dan Grashof seperti yang digambarkan pada persamaan (6):

$$
R a=G r \cdot P r
$$

Prandtl Number bisa didapatkan ketika kita sudah mengetahui temperatur udara pada saat terjadi konveksi, sedangkan nilai Grashof Number diambil dari persamaan (7):

$$
G r=\frac{g \beta\left(T_{s}-T_{\infty}\right) L c^{3}}{v^{2}}
$$

Nilai Grashof Number dapat diambil ketika nilai gravitasi, koefisien ekspansi thermal , perbedaan suhu antar permukaan dan lingkungan, panjang karakteristik dan kinematic viscocity udara (diambil dari data tabel Cengel, 2008). Sama seperti halnya bilangan Reynolds pada pengukuran aliran fluida, Grashof mengidentifikasikan perilaku fluida pada konveksi natural, di mana ketika nilainya $10^{3}$ sampai $10^{6}$ masih dalam tahap laminar dan $10^{8}$ sampai $10^{9}$ masuk ke dalam fluida turbulen.

Generasi panas terhadap material pada perubahan temperatur tertentu dapat dihitung menggunakan perumusan sebagai berikut:

$$
Q=m \cdot C p \cdot \frac{\partial T}{\partial t}
$$

Massa baterai dan perubahan temperatur pada baterai penulis dapatkan dari pengukuran eksperimen yang penulis lakukan, sedangkan kalor jenisnya (Cp) didapatkan dari referensi penulis, yaitu Cp: $894 \mathrm{~J} / \mathrm{kg} . \mathrm{K}$ (Zhang, 2018).

Sebagai kondisi penelitian, penulis memakai referensi dari penelitian Xiao Xuan Zhang (2018), sehingga didapatkan kalor jenisnya Cp: $894 \mathrm{~J} / \mathrm{kg} . \mathrm{K}$. Untuk densitasnya penulis melakukan pengukuran langsung terhadap baterai dan didapatkan densitas baterai $\rho: 2604.92$ $\mathrm{kg} / \mathrm{m}^{3}$. Referensi yang penulis dapatkan dari S.S.Chen (2004) memberikan nilai konduktivitas thermal pada baterai ion lithium dengan nilai konduktivitas nya adalah $1.035 \mathrm{~W} / \mathrm{m}$.K. Kondisi 
suhu pada ruangan adalah $26{ }^{\circ} \mathrm{C}(299 \mathrm{~K})$, sehingga untuk suhu pada baterai akan diselisihkan dengan suhu ruangan tersebut agar diketahui kenaikan suhunya.

Pada penelitian ini, penulis memakai baterai ion Lithium Samsung 25R dengan tipe 18650. Dari spesifikasi baterai, didapatkan bahwa baterai bisa dioperasikan hingga: Arus discharge baterai $\leq 20 \mathrm{~A}(8$ kali Capacity $=8 \mathrm{C})$, Temperature baterai $\leq 60^{\circ} \mathrm{C}$. Di penelitian ini, baterai hanya akan melakukan discharge dengan maksimal $10 \mathrm{~A}(3.5 \mathrm{C})$ dan penelitian akan dihentikan jika suhu sudah melebihi dari $60^{\circ} \mathrm{C}$, agar mencegah kerusakan baterai. Data-data yang telah didapatkan dengan eksperimen akan dibuat simulasi dan akan dilakukan validasi kembali dengan data eksperimental.

Setelah didapatkan data eksperimen, maka penulis menghitung panas yang timbul pada baterai, dan dimasukan ke dalam simulasi ANSYS. Kondisi pada simulasi penulis tetapkan sebagai berikut:

1. Kalor jenis: $894 \mathrm{~J} / \mathrm{kg} . \mathrm{K}$

2. Pemanasan karena reaksi kimia diabaikan

3. Suhu lingkungan (udara): $26^{\circ} \mathrm{C}$

4. Suhu awal baterai $26.7^{\circ} \mathrm{C}$

5. Kondisi thermal runway (ketika voltase jatuh mendekati titik 0 Volt dan terjadi kenaikan suhu mendadak) tidak diperhitungkan, sehingga kondisi yang diperhitungkan adalah ketika baterai beroperasi normal

6. Hambatan dan panas dari kabel tidak diabaikan

7. Simulasi dilakukan transient dengan lama waktu operasi baterai

8. Diasumsikan perpindahan panas hanya terjadi secara radial

Pemodelan pada simulasi numerik digambarkan sebagai berikut:

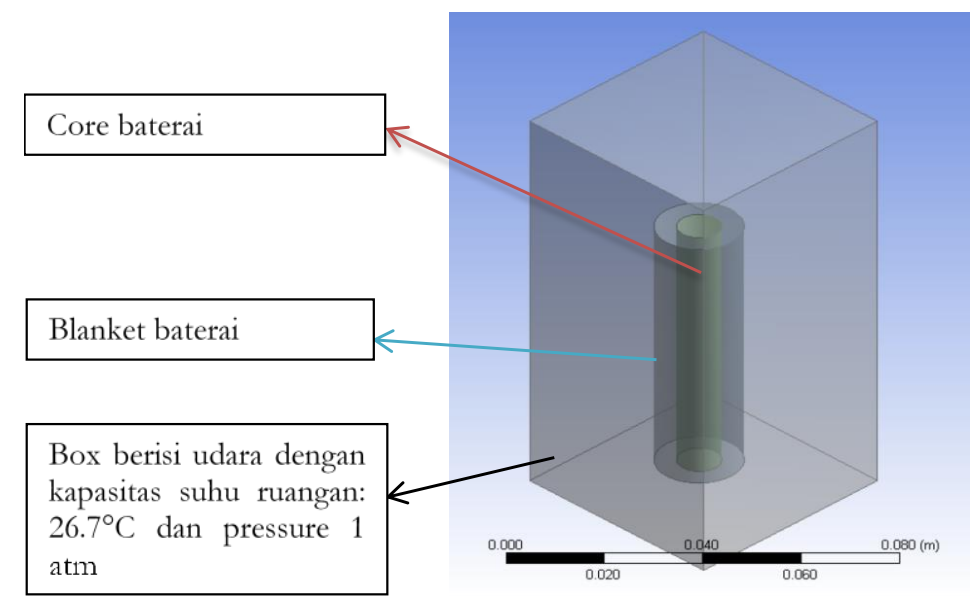

Gambar 2. Skematik simulasi yang dilakukan

Model berisi core, di mana generasi panas dilakukan (dilakukan perhitungan pemanasan material), blanket di mana konduksi terjadi dan box berisi udara. Dengan skema tersebut, simulasi akan dijalankan transient selama beberapa waktu. Lama waktu simulasi akan bergantung dari perhitungan dan hasil eksperimen pada baterai. 


\section{HASIL DAN PEMBAHASAN}

Penulis melakukan eksperimen dengan 1 sel baterai untuk mengetahui laju panas yang dihasilkan oleh baterai. Baterai tersebut dihubungkan dengan varian output sesuai dengan yang dijelaskan di bagian metode penelitian, sehingga bisa diketahui hubungan antara waktu dengan arus keluaran dan temperaturnya.

Eksperimen yang dilakukan pada baterai individual adalah dengan melakukan varian pada outputnya. Penulis membuat resistor sesuai dengan yang dijelaskan di metode penelitian, dan melakukan pengukuran panas dengan IR camera. Terdapat hasil yang didapatkan adalah sebagai berikut:

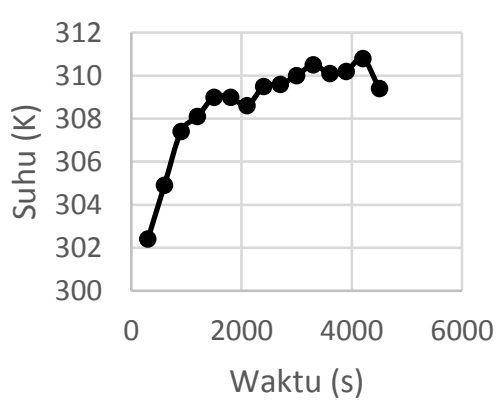

(a)

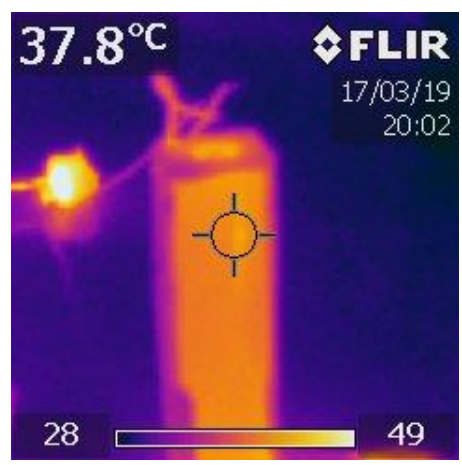

(b)

Gambar 3. (a) Grafik waktu vs suhu dengan variasi output $1.5 \mathrm{ohm}$, (b) Suhu maksimal dari beban 1.5 ohm dengan IR Thermal Camera

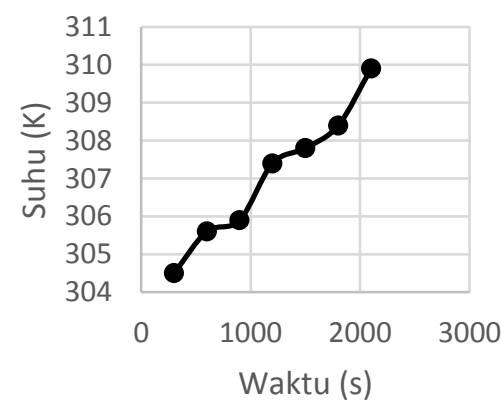

(a)

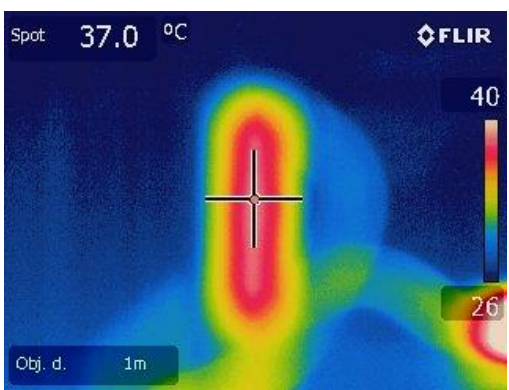

(b)

Gambar 4. (a) Grafik waktu vs suhu dengan output baterai $1 \mathrm{ohm}$, (b) Suhu maksimal dari beban $1 \mathrm{ohm}$ dengan IR Thermal Camera 


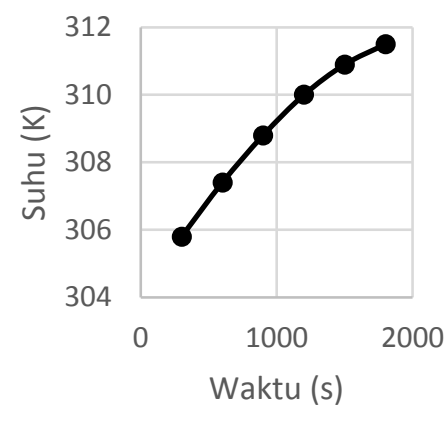

(a)

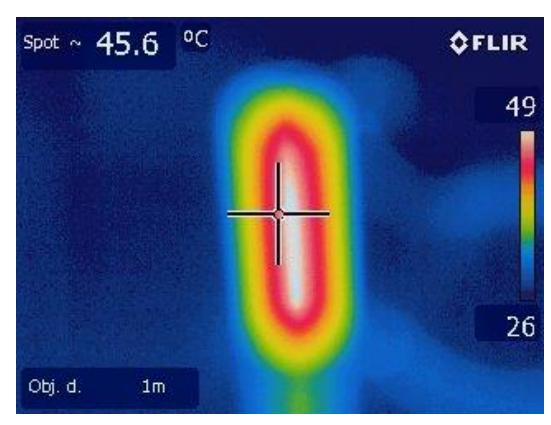

(b)

Gambar 5.(a) Grafik waktu vs suhu keluaran dengan output $0.8 \mathrm{ohm}$, (b) Suhu maksimal dari beban 0.8 ohm dengan IR Thermal Camera

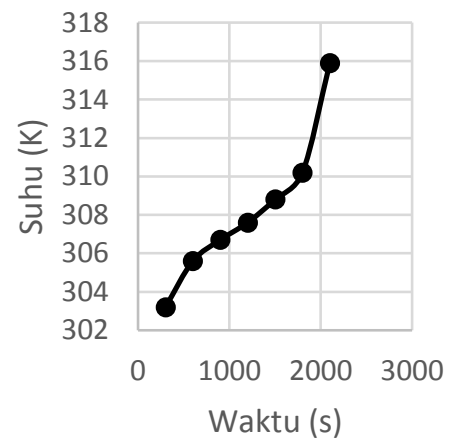

(a)

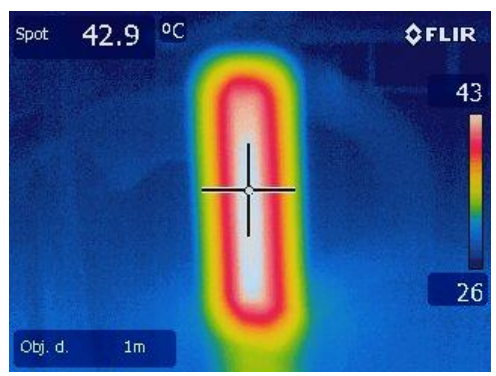

(b)

Gambar 6. (a)Grafik waktu vs suhu keluaran dengan output $0.7 \mathrm{ohm}$, (b) Suhu maksimal dari beban 0.7 ohm dengan IR Thermal Camera

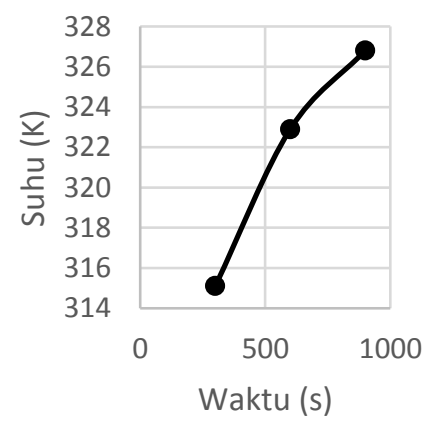

(a)

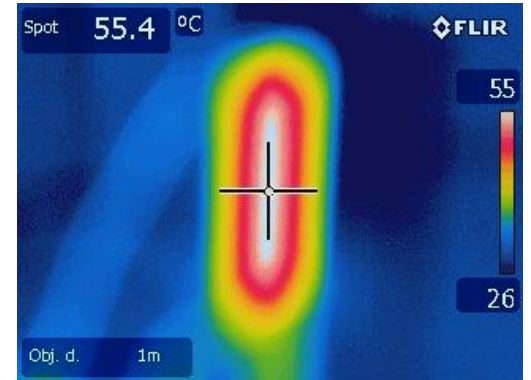

(b)

Gambar 7. (a) Grafik waktu vs suhu keluaran dengan output $0.4 \mathrm{ohm}$, (b) Suhu maksimal dari beban 0.4 ohm dengan IR Thermal Camera

Selama pengamatan, baterai dioperasikan sampai kondisi voltasenya mendekati $0 \mathrm{~V}$. Suhu baterai yang diukur dengan IR Camera menghasilkan hasil yang ditampilkan oleh Gambar 
3 sampai Gambar 7. Dari data tersebut, dapat diketahui bahwa titik temperatur pada baterai semakin tinggi ketika output ohmnya semakin kecil. Terlihat pada beban $0.4 \mathrm{ohm}$, temperatur mencapai $326 \mathrm{~K}$, sedangkan pada keluaran beban $1.5 \mathrm{ohm}$ temperatur hanya mencapai suhu 310 K. Kenaikan temperatur pun tidak mempunyai karakterisitik yang beragam, hal ini disebabkan oleh internal resistance baterai yang tidak konstan, mengakibatkan arus yang didapat oleh baterai berbeda-beda pada tiap sel baterai. Dari arus yang berbeda akan didapatkan generasi panas yang berbeda sehingga membuat kenaikan temperatur yang berbeda.

Pada pengamatan temperature yang disebutkan pada Gambar 3 sampai 7, terdapat pengumpulan panas di tengah baterai yang melakukan perpindahan panas ke permukaan baterai, dan hanya sedikit persembaran panas ke atas atau dasar baterai. Dengan mengabaikan persebaran ke arah z, Pemodelan perpindahan panas pada baterai secara $2 \mathrm{D}$ akan didapat seperti pada Gambar 8:

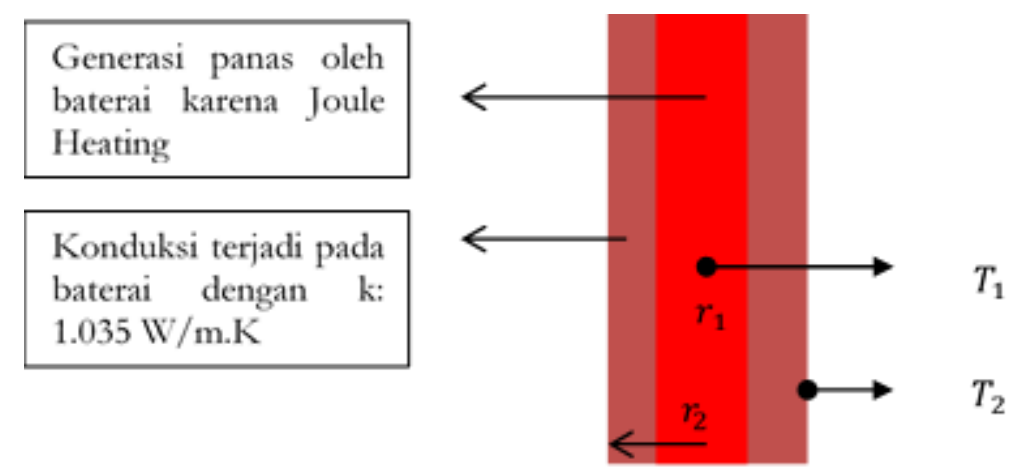

Gambar 8. Skema perpindahan panas konduksi 2D pada baterai 1

Perpindahan panas terjadi dari Joule Heating memanaskan diasumsikan terjadi pada tengah baterai dan diteruskan ke permukaan baterai dengan konduktivitas dari baterai ion lithium, lalu secara konveksi natural panas akan diteruskan ke udara lingkungan. Perhitungan panas terhadap baterai dihitung dengan memakai perhitungan konduksi dan konveksi yang dihasilkan oleh baterai seperti pada persamaan (2) dan (3), di mana persamaan tersebut menunjukkan bahwa generasi panas yang dihasilkan baterai akan diteruskan dengan konduksi dan konveksi. Konduksi akan diterima oleh body baterai, sedangkan konveksi akan dilakukan ke udara sekitar. Pada konduksinya, perhitungan dilakukan dengan menghitung kalor dengan m.Cp.dT/dt, di mana datanya dapat dihitung dengan data dari hasil eksperimen. Sedangkan konveksinya perhitungan dengan $h . A .\left(T_{s}-T_{f}\right)$ membutuhkan nilai $b$ yang tepat selama konveksinya. Pada penelitian ini konveksi diasumsikan secara natural, karena tidak ada force udara dari luar secara konstan. Persamaan 4.4 ini dipakai pada penelitian dari Liu (2013) dan Onorati (2009), di mana hasil dari penelitiannya dapat memprediksi generasi panas pada baterai dengan hasil yang cukup akurat.

Besarnya konduksi dari eksperimen akan dihitung dengan perumusan m.Cp. $(d T / d t)$. Dengan mengetahui massa baterai: 45 gram dan Cp: $894 \mathrm{~W} / \mathrm{m} . \mathrm{K}$, didapatkan hasil sebagai berikut: 
Tabel 1. Perhitungan panas konduksi pada baterai 1

\begin{tabular}{llll}
$\begin{array}{l}\mathbf{R} \\
(\mathbf{o h m})\end{array}$ & $\begin{array}{l}\mathbf{d T} \\
(\mathbf{K})\end{array}$ & $\begin{array}{l}\mathbf{d t} \\
\text { (detik) }\end{array}$ & $\boldsymbol{m} \cdot \boldsymbol{C p} \cdot \frac{\boldsymbol{d} \boldsymbol{T}}{\boldsymbol{d t}}(\mathbf{W})$ \\
\hline $\mathbf{1 . 5}$ & 11.1 & 4200 & 0.11 \\
$\mathbf{1}$ & 10.2 & 2100 & 0.20 \\
$\mathbf{0 . 8}$ & 12 & 2100 & 0.23 \\
$\mathbf{0 . 7}$ & 16.2 & 2100 & 0.31 \\
$\mathbf{0 . 4}$ & 27.1 & 900 & 1.21
\end{tabular}

Pada table 1 ini $\mathrm{R}$ merupakan varian beban keluaran dari penelitian, sedangkan dT adalah perbedaan temperature dari awal hingga baterai hamper habis, dan dt adalah lama operasi baterainya. Dengan didapatkan energi konduksi pada baterai dan konduktivitas pada baterai, maka bisa diketahui distribusi panas pada baterai. Sesuai dengan skema perpindahan panas pada Gambar 8, perpindahan panas bisa dihitung dengan menggunakan persamaan (1) sebagai dasarnya, namun karena perpindahan panas dianggap hanya terjadi secara radial, luas area $A$ dalam persamaan (1) bisa diubah menjadi:

$$
\frac{Q}{2 \pi r L}=-k \frac{d T}{d r}
$$

Pada persamaan ini $Q / 2 \pi L$ bisa dianggap sebagai flux panas $(q$ '), di mana nilai ini bisa dianggap sebagai laju perpindahan panas yang terjadi pada baterai. Namun untuk mengetahui temperatur pada tepi baterai diperlukan perhitungan sebagai berikut:

$$
\begin{aligned}
& \frac{Q}{2 \pi L} \int_{r_{1}}^{r_{2}} \frac{d r}{r}=-k \int_{T_{1}}^{T_{2}} d T \\
& \frac{Q}{2 \pi L} \ln \left(\frac{r_{2}}{r_{1}}\right)=k\left(T_{1}-T_{2}\right) \\
& Q=2 \pi L k \frac{\left(T_{1}-T_{2}\right)}{\ln \left(\frac{r_{2}}{r_{1}}\right)} \\
& \left(T_{1}-T_{2}\right)=\frac{Q}{2 \pi L k} \cdot \ln \left(\frac{r_{2}}{r_{1}}\right)
\end{aligned}
$$

Dengan persamaan (13) dan nilai $Q$ dari Tabel 1 , didapatkan $T_{2}$ sebagai temperatur permukaan baterai. Sehingga nilai temperature baterai pada eksperimen adalah sebagai berikut:

Tabel 2. Perhitungan konduksi dan temperature pada baterai2

\begin{tabular}{llllll}
\hline $\begin{array}{l}\mathbf{R} \\
(\mathbf{o h m})\end{array}$ & $\begin{array}{l}\mathbf{Q} \\
(\mathbf{W a t t})\end{array}$ & $\begin{array}{l}\boldsymbol{q}^{\mathbf{K}} \mathbf{\mathbf { m } ^ { 2 } )} \\
(\mathbf{1})\end{array}$ & $\boldsymbol{T}_{\mathbf{1}}-\boldsymbol{T}_{\mathbf{2}} \mathbf{( K )}$ & $\begin{array}{c}\boldsymbol{T}_{\mathbf{1}} \\
(\mathbf{K})\end{array}$ & $\begin{array}{c}\boldsymbol{T}_{\mathbf{2}} \\
(\mathbf{K})\end{array}$ \\
\hline $\mathbf{1 , 5}$ & 0,11 & 0.92 & 0,62 & 310,80 & 310,18 \\
$\mathbf{1}$ & 0,20 & 1.69 & 1,13 & 309,90 & 308,77 \\
$\mathbf{0 , 8}$ & 0,23 & 1.99 & 1,33 & 311,70 & 310,37 \\
$\mathbf{0 , 7}$ & 0,31 & 2.69 & 1,80 & 315,90 & 314,10 \\
$\mathbf{0 , 4}$ & 1,21 & 4.59 & 3,02 & 326,80 & 323,78 \\
\hline
\end{tabular}


Dengan mengetahui besaran temperatur permukaan $T_{2}$, maka bisa dianalisa konveksi natural yang terjadi pada baterai.

Perhitungan konveksi pada baterai dengan persamaan h.A. $\left(T_{s}-T_{f}\right)$ akan membutuhkan nilai temperature film yang terjadi $T_{f}$ ketika terjadi konveksi. Perhitungan nilai $T_{f}$ dapat didekati dengan persamaan sebagai berikut:

$$
T_{f}=\frac{T_{s}+T_{\infty}}{2}
$$

Karena ada 2 suhu permukaan yang kontak dengan udara lingkungan, pada penelitian ini penulis memperhitungkan konveksi $T_{1}$ dengan panjang karakteristik diameter baterai dan $T_{2}$ dengan panjang karakteristik tinggi baterai. Konveksi yang terjadi akan dijumlahkan sehingga disa idapatkan total energi konveksi yang dikeluarkan oleh baterai. Untuk menganalisa konveksi yang terjadi perlu diketahui koefisien konveksi $b$ yang ada pada pada udara lingkungan dengan mencari Nussault Number $N u$ yang terjadi pada pelepasan kalor dari permukaan baterai ke lingkungan. Perhitungan Nussault number didapat dengan persamaan (5) sampai persamaan (7). Nilai Prandtl, konduksi pada udara, dan nilai kinematic viscocity di dapatkan dengan melakukan interpolasi data dari Tabel 1 atm udara (Cengel, 2008). Dari perhitungan yang dilakukan, didapatkan data sebagai berikut:

Tabel 3. Hasil Perhitungan $T_{f}, \beta$, Prandtl Number, konduktivitas thermal dan kinematic viscosity pada udara $1 \mathrm{~atm} 3$

\begin{tabular}{lccccccc}
\hline $\begin{array}{c}\mathbf{R} \\
(\mathbf{o h m})\end{array}$ & $\begin{array}{c}\boldsymbol{T}_{\boldsymbol{s}} \\
(\mathbf{K})\end{array}$ & $\begin{array}{c}\boldsymbol{T}_{\infty} \\
(\mathbf{K})\end{array}$ & $\begin{array}{c}\boldsymbol{T}_{\boldsymbol{f}} \\
(\mathbf{K})\end{array}$ & $\boldsymbol{\beta}$ & $\mathbf{P r}$ & $\begin{array}{c}\boldsymbol{k} \\
(\mathbf{W} / \mathbf{m . k})\end{array}$ & $\begin{array}{c}\boldsymbol{v} \\
\left(\mathbf{m}^{2} / \mathbf{s}\right)\end{array}$ \\
\hline $\mathbf{1 . 5 0}$ & 310.80 & 299.70 & 305.25 & 0.00328 & 0.7276 & 0.02605 & 0.0000163 \\
& 310.18 & 299.70 & 304.94 & 0.00328 & 0.7277 & 0.02602 & 0.0000163 \\
$\mathbf{1 . 0 0}$ & 309.90 & 299.70 & 304.80 & 0.00328 & 0.7277 & 0.02601 & 0.0000162 \\
& 308.77 & 299.70 & 304.23 & 0.00329 & 0.7279 & 0.02597 & 0.0000162 \\
$\mathbf{0 . 8 0}$ & 311.70 & 299.70 & 305.70 & 0.00327 & 0.7274 & 0.02608 & 0.0000163 \\
& 310.37 & 299.70 & 305.03 & 0.00328 & 0.7276 & 0.02603 & 0.0000163 \\
$\mathbf{0 . 7 0}$ & 315.90 & 299.70 & 307.80 & 0.00325 & 0.7269 & 0.02624 & 0.0000165 \\
& 314.10 & 299.70 & 306.90 & 0.00326 & 0.7271 & 0.02617 & 0.0000164 \\
$\mathbf{0 . 4 0}$ & 326.80 & 299.70 & 313.25 & 0.00319 & 0.7255 & 0.02420 & 0.0000170 \\
& 323.78 & 299.70 & 311.74 & 0.00321 & 0.7263 & 0.02638 & 0.0000167 \\
\hline
\end{tabular}

Tabel 4. Perhitungan Q konveksi pada baterai4

\begin{tabular}{lcclllll}
\hline $\begin{array}{c}\mathbf{R} \\
(\mathbf{o h m})\end{array}$ & $\begin{array}{c}\boldsymbol{T}_{\boldsymbol{f}} \\
(\mathbf{K})\end{array}$ & \multicolumn{1}{c}{$\mathbf{G r}$} & \multicolumn{1}{c}{$\mathbf{R a}$} & $\mathbf{N u}$ & $\begin{array}{c}\boldsymbol{h} \\
\left(\mathbf{W} / \mathbf{m}^{2} \mathbf{K}\right)\end{array}$ & $\begin{array}{c}\boldsymbol{Q} \\
(\mathbf{W})\end{array}$ & $\begin{array}{c}\boldsymbol{Q} \text { total } \\
(\mathbf{W})\end{array}$ \\
\hline $\mathbf{1 . 5}$ & 305.25 & $8,364.21$ & $6,085.55$ & 3.04 & 4.30 & 0.003 & 0.10 \\
& 304.94 & $349,857.00$ & $254,575.64$ & 12.13 & 4.86 & 0.101 & \\
$\mathbf{1}$ & 304.80 & $7,737.50$ & $5,630.55$ & 3.00 & 4.23 & 0.003 & 0.09 \\
& 304.23 & $305,796.29$ & $222,575.22$ & 11.73 & 4.69 & 0.084 & \\
$\mathbf{0 . 8}$ & 305.70 & $8,982.37$ & $6,534.17$ & 3.07 & 4.36 & 0.003 & 0.11 \\
& 305.03 & $355,507.43$ & $258,678.06$ & 12.18 & 4.88 & 0.103 & \\
$\mathbf{0 . 7}$ & 307.80 & $11,757.56$ & $8,546.05$ & 3.22 & 4.60 & 0.005 & 0.15 \\
\hline
\end{tabular}


A. Kurniawan / Journal of Mechanical Design and Testing 2(2), (2020), 87-102

\begin{tabular}{llllllll}
\hline \multirow{3}{*}{$\mathbf{0 . 4}$} & 306.90 & $466,890.61$ & $339,479.81$ & 13.03 & 5.25 & 0.149 & \\
& 313.25 & $18,232.18$ & $13,227.45$ & 5.79 & 7.62 & 0.014 & 0.24 \\
& 309.74 & $624,569.08$ & $453,654.32$ & 14.01 & 5.69 & 0.226 & \\
\hline
\end{tabular}

Dengan didapatkan pehitungan konveksi dari Tabel 4, dapat diketahui Q internal baterai. Hasil perhitungan tersebut akan dimasukan ke dalam simulasi numerik pada penelitian.

Pembuatan model numerik untuk penelitian ini dimulai dengan pembuatan geometri baterai. Untuk memfasilitasi konveksi yang terjadi, penulis juga membuatkan sebuah ruangan udara dengan kondisi pressure $1 \mathrm{~atm}$ agar bisa dilihat transfer konveksi yang terjadi. Pemodelan baterai penulis sesuaikan dengan ukuran sebenarnya dari baterai dengan diameter 18,4 $\mathrm{mm}$ dan tinggi $65 \mathrm{~mm}$. Pada bagian baterai, penulis membuatkan 2 bagian: core dan blanket, di mana core baterai akan menjadi sumber panas pada baterai, sedangkan blanket hanya mengalirkan panas secara konduksi dari core dan memberikan konveksi ke udara ruangan. Core pada baterai berdiameter $9.2 \mathrm{~mm}$, sedangkan blanketnya berdiameter total baterai: $18.4 \mathrm{~mm}$.

Pemodelan ruangan udara pada 1 sel baterai penulis buatkan dengan ukuran $50 \mathrm{~mm}$ x $50 \mathrm{~mm} \times 100 \mathrm{~mm}$. Sehingga didapatkan pemodelan seperti yang dijelaskan pada Gambar 2 . Gemoteri dari Gambar 2 akan dibuat mesh agar bisa dibuat perhitungan numerik pada model tersebut. Dengan mesh yang baik, perhitungan yang akurat bisa dihasilkan sehingga bisa mendapatkan validasi yang baik. Untuk pengetesan kualitas mesh nya, penulis membuat pengetesan dengan berbagai macam mesh sehingga didapatkan hasil yang cukup stabil dari initial condition dari penulis.

Untuk pengecekan mesh nya, penulis membuatkan independent test. Sebagai masukannya, core baterai penulis berikan masukan temperatur konstan setinggi $500 \mathrm{~K}$ selama 1 menit sehingga pada blanketnya dapat terjadi konduksi dan bisa melakukan konveksi pada sekitar baterai. Penulis akan dilakukan perbedaan transfer panas di bidang atas baterai. Perbandingannya adalah sebagai berikut:

Tabel 5. Hasil independent test 5

\begin{tabular}{|l|l|l|}
\hline Jumlah sel meshing & Temperatur dinding & Deviation \\
\hline $\mathbf{6 8 . 5 5 4}$ & 453 & - \\
\hline $\mathbf{9 0 . 8 2 1}$ & 454.5 & $3,32 \%$ \\
\hline $\mathbf{1 2 0 . 5 6 3}$ & $454 ., 6$ & $0.22 \%$ \\
\hline $\mathbf{2 6 9 . 9 7 4}$ & 454,7 & $0.21 \%$ \\
\hline
\end{tabular}




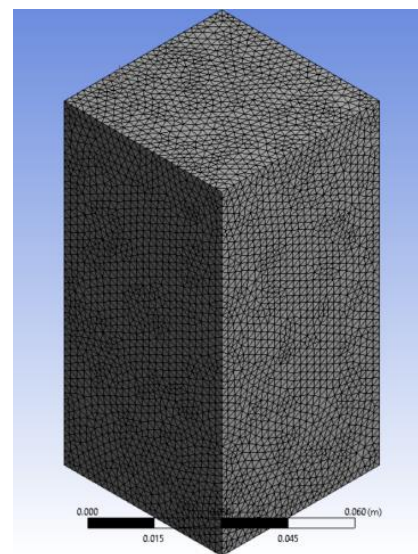

(a)

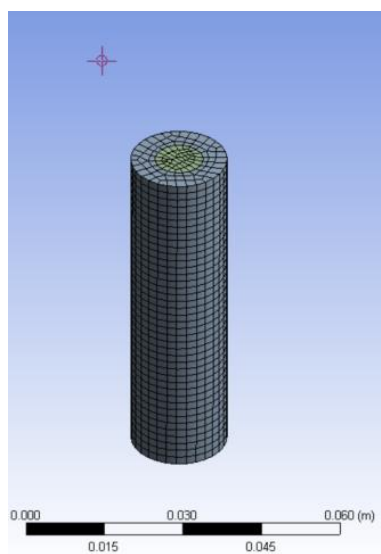

(b)

Gambar 9. Penampakan hasil meshing (a) ruang udara dan (b) sel baterai yang dipakai untuk simulasi 2

Dengan hasil dari tabel 5, penulis memakai jumlah sel 269.974 untuk pemodelannya. Dari model tersebut didapatkan nilai rata-rata skewness pada sel: 0,229. Dengan kualitas mesh yang cukup baik, maka penelitian bisa dilanjutkan untuk memasukan boundary dan initial condition.

Penentuan boundary condition dan initial condition penulis ambil dari sumber referensi dan hasil penelitian. Data-data yang telah didapatkan terhadap arus, temperature waktu dan outputnya bisa dimasukan ke dalam simulasi dengan berdasarkan data yang telah didapatkan. Untuk material baterai, penulis masukan kalor jenisnya senilai Cp: 894 J/kg.K (Zhang, 2018). Sedangkan untuk densitasnya, penulis mendapatkan data dari pengukuran langsung dari baterai bernilai $\rho: 2604,92 \mathrm{~kg} / \mathrm{m}^{3}$.

Input panas pada baterai penulis masukkan ke dalam cell qone condition agar pada body baterai bisa mengelurakan panas yang bertambah dalam waktu operasi sesuai dengan data eksperimen. Nilai panas konduksi dan konveksi yang dihitung akan dimasukan sebagai input pada core baterai. Setelah mengetahui nilai $Q$ total konduksi dan konveksi baterai pada tiap variannya, nilai $Q$ total akan dibagi dengan volume core baterai yang bernilai 4,319 $\times 10^{-6} \mathrm{~m}$ sehingga didapatkan nilai panas per volume nya. Hasil yang didapat ditampilkan dalam Tabel 6:

Tabel 6. Perhitungan $q^{\prime \prime \prime}$ pada baterai6

\begin{tabular}{|l|l|l|l|l|l|}
\hline $\begin{array}{l}\mathbf{R} \\
(\mathbf{o h m})\end{array}$ & $\begin{array}{l}\boldsymbol{Q} \text { konduksi } \\
(\mathbf{W})\end{array}$ & $\begin{array}{l}\boldsymbol{Q} \text { konveksi } \\
(\mathbf{W})\end{array}$ & $\begin{array}{l}\boldsymbol{Q} \text { internal } \\
(\mathbf{W})\end{array}$ & $\begin{array}{l}\boldsymbol{q}^{\prime \prime \prime} \\
\left(\mathbf{W} / \mathbf{m}^{3}\right)\end{array}$ & $\begin{array}{l}\boldsymbol{q}^{\mathbf{}} \\
\left(\mathbf{W} / \mathbf{m}^{2}\right)\end{array}$ \\
\hline $\mathbf{1 , 5}$ & 0,11 & 0,10 & 0,21 & $48.663,23$ & 0.92 \\
\hline $\mathbf{1}$ & 0,20 & 0,09 & 0,29 & $65.366,07$ & 1.69 \\
\hline $\mathbf{0 , 8}$ & 0,23 & 0,11 & 0,34 & $77.854,66$ & 1.99 \\
\hline $\mathbf{0 , 7}$ & 0,31 & 0,15 & 0,46 & $107.607,59$ & 2.69 \\
\hline $\mathbf{0 , 4}$ & 1,21 & 0,24 & 1,45 & $335.953,18$ & 4.59 \\
\hline
\end{tabular}

Setelah memasukan nilai q"” ke dalam core baterai dan $q$ ” pada sisi dalam blanket baterai, penulis memasukan pula nilai gravitasi $9,8 \mathrm{~m} / \mathrm{s}^{2}$ agar terjadi konveksi natural pada simulasi. Udara dalam box juga di set dengan nilai pressure 1 atm dengan suhu $299 \mathrm{~K}$, sesuai dengan kondisi eksperimen. Dengan nilai boundary condition yang sudah didapatkan, penulis bisa 
melakukan running simulasi dengan waktu operasi sesuai dengan eksperimen yang ditampilkan pada Tabel 1 dalam kondisi transient.

Simulasi yang dilakukan terhadap beban keluaran 1,5 ohm menghasilkan hasil persebaran panas seperti dalam Gambar 10. Pada tampilan hasil simulasi ini, penulis melakukan setting pewarnaan pada contour temperature dengan rentang $299 \mathrm{~K}$ sampai $330 \mathrm{~K}$ agar bisa dibandingkan hasil simulasi tiap variannya.

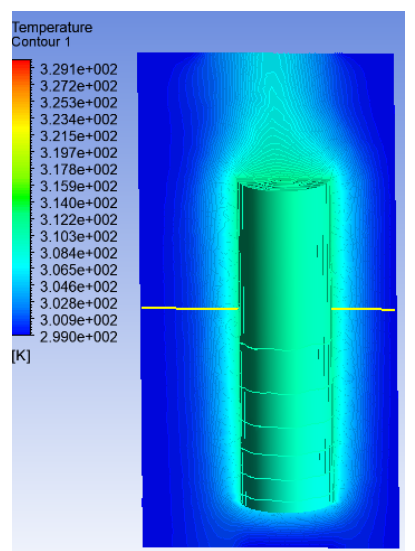

(a)

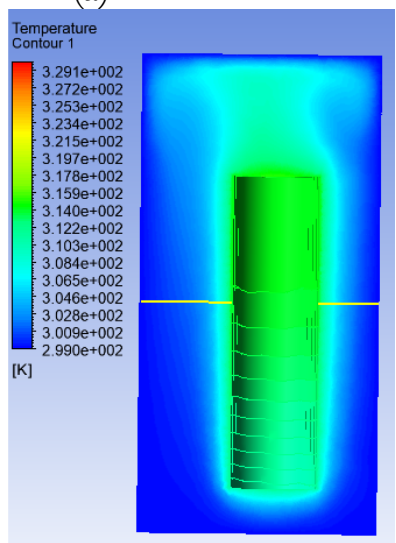

(d)

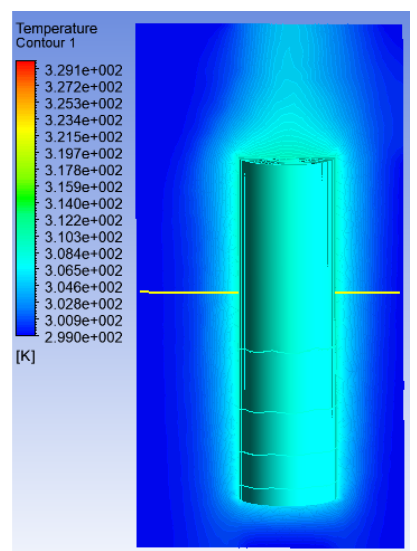

(b)

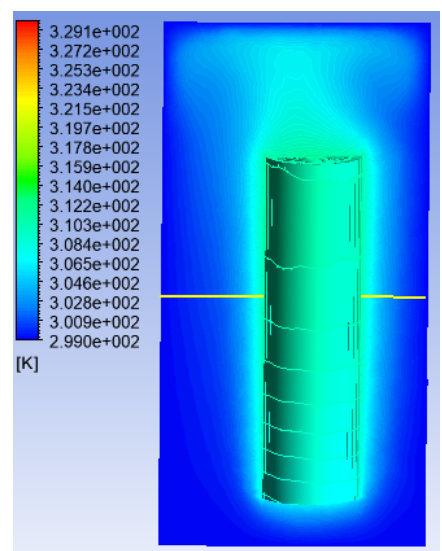

(c)

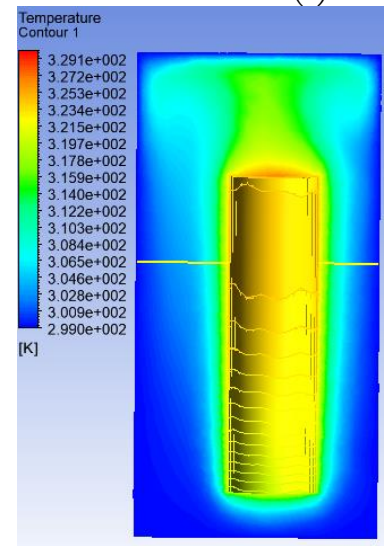

(e)

Gambar 10. Hasil simulasi distribusi temperatur pada baterai dan lingkungannya dengan beban (a) 1.5 ohm, (b) $1 \mathrm{ohm},(\mathrm{c}) 0.8 \mathrm{ohm},(\mathrm{d}) 0.7 \mathrm{ohm}$, (e) $0.4 \mathrm{ohm} 3$

Pada Gambar 10 dapat terlihat persebaran panas yang dilakukan oleh konveksi baterai memiliki kecenderungan menyebar ke atas, sesuai dengan prinsip konveksi natural di mana udara panas akan memiliki buoyany force yang lebih tinggi dibandingkan udara yang lebih dingin. Untuk mendapatkan detail distribusi temperatur yang terjadi pada simulasi, penulis membuat garis sample temperature yang berwarna kuning di Gambar 10. Temperatur yang dihasilkan pada simulasi kemudian dibandingkan dengan perhitungan penulis pada Tabel 2, sehingga didapatkan data sebagai berikut: 
Tabel 7. Perbandingan nilai perhitungan dengan simulasi

\begin{tabular}{lcccc}
\hline $\begin{array}{c}\mathbf{R} \\
\mathbf{o h m})\end{array}$ & $\begin{array}{c}\boldsymbol{T}_{\mathbf{1}} \\
\text { perhitungan } \\
(\mathbf{K})\end{array}$ & $\begin{array}{c}\boldsymbol{T}_{\mathbf{1}} \\
\text { simulasi } \\
(\mathbf{K})\end{array}$ & $\begin{array}{c}\boldsymbol{T}_{\mathbf{2}} \\
\text { perhitungan } \\
(\mathbf{K})\end{array}$ & $\begin{array}{c}\boldsymbol{T}_{\mathbf{2}} \\
\text { simulasi } \\
(\mathbf{K})\end{array}$ \\
\hline $\mathbf{1 , 5}$ & 310,80 & 311,5 & 310,18 & 310,8 \\
$\mathbf{1}$ & 309,90 & 309,3 & 308,77 & 308,6 \\
$\mathbf{0 , 8}$ & 311,70 & 311 & 310,37 & 310 \\
$\mathbf{0 , 7}$ & 315,90 & 315 & 314,10 & 313,9 \\
$\mathbf{0 , 4}$ & 326,80 & 327 & 323,78 & 324 \\
\hline
\end{tabular}

Pada Tabel 7 ini, terlihat persebaran konduksi panas simulasi dengan perhitungan tidak berbeda jauh, di mana nilainya mirip dengan perhitungan konduksi yang dilakukan di Tabel 2 .

Pada beban 1,5 ohm, di mana perbedaan suhu antara pusat baterai hingga ke ujungnya hanya terpaut $0,62 \mathrm{~K}$. Hasil panas yang dihasilkan oleh baterai dari dalam baterai mencapai 311,5 $\mathrm{K}$, mempunyai selisih sedikit dengan hasil eksperimen di mana puncak panasnya mencapai 310,8 $\mathrm{K}\left(37,8^{\circ} \mathrm{C}\right)$. Dengan perbedaan $0,7 \mathrm{~K}$ terhadap rentang $299 \mathrm{~K}-310 \mathrm{~K}$, error pada simulasi pada beban 1,5 ohm ini hanya sekitar $6 \%$.

Pada beban $1 \mathrm{ohm}$, distribusi panas yang dihasilkan cukup mirip dengan simulasi. Pada eksperimen, titik suhu tertinggi yang dicapai pada varian $1 \mathrm{ohm}$ adalah $310 \mathrm{~K}\left(37^{\circ} \mathrm{C}\right)$, sedangkan pada simulasi suhu maksimum yang dicapai adalah 309,3 K. Perhitungan konduksi perhitungan menghasilkan perbedaan temperatur $1,18 \mathrm{~K}$ dari titik tengah ke titik permukaan baterai, namun pada simulasi perbedaan temperatur dari titik tengah ke permukaannya hanya terpaut sekitar 0,7 K. . Dengan rentang $299 \mathrm{~K}-310 \mathrm{~K}$, error pada simulasi ini hanya sebanyak 6\%.

Pada beban 0,8 ohm terlihat suhu tertinggi pada simulasi yang terdapat di core baterai mencapai $311 \mathrm{~K}$ sedangkan di permukaann baterai suhunya didapatkan $310 \mathrm{~K}$. Hal ini cukup mirip dengan perhitungan, di mana perbedaan suhu dari core baterai ke permukaan baterai didapatkan 1,33 $\mathrm{K}$ dengan suhu core baterai 311,7 $\mathrm{K}$ dan permukaan suhu baterai 310,37. Terdapat perbedaan $0,33 \mathrm{~K}$ pada simulasi dan eksperimen, sehingga didapatkan nilai error sebesar 3\%.

Pada simulasi beban $0,7 \mathrm{ohm}$, Joule heating mencapai suhu $315 \mathrm{~K}$ dan panasnya diteruskan dengan konduksi sehingga permukaan baterai memiliki suhu 313,9 K. Namun pada perhitungan dari eksperimen di Tabel 5.2, nilai suhu pada core baterai adalah 315,9 K sedangkan suhu permukaan baterainya adalah 314,1 K. Adanya perbedaan maksimum 0,9 K ini membuat nilai error pada simulasi ini sebesar $6 \%$.

Pada simulasi beban 0,4 ohm, Joule heating pada core baterai mencapai suhu $327 \mathrm{~K}$ dan panasnya diteruskan dengan konduksi di mana suhu permukaannya di dapat $324 \mathrm{~K}$. Namun pada perhitungan dari eksperimen di Tabel 5.2, nilai suhu pada core baterai adalah 326,8 K sedangkan suhu permukaan baterainya adalah $323,78 \mathrm{~K}$. Adanya perbedaan maksimum 0,32 K ini membuat nilai error pada simulasi ini sebesar $1 \%$.

\section{KESIMPULAN}

Dari Penelitian terhadap baterai lithium ion 18650 ini mendapatkan kesimpulan sebagai berikut: 
1. Panas pada baterai terjadi disebabkan sebagian besar Joule Heating yang terjadi karena adanya arus listrik melewati hambatan pada internal baterai. Besarnya Joule heating akan sangat dipengaruhi oleh arus listrik yang dikeluarkan oleh baterai, di mana keluaran arus listrik akan dipengaruhi oleh hambatan keluaran, sesuai dengan hukum ohm. Joule heating yang dilakukan oleh baterai akan diteruskan ke seluruh body baterai melalui konduksi dan diteruskan ke udara melalui proses konveksi.

2. Laju panas pada internal baterai dapat dihitung dengan mengetahui besaran laju perpindahan panas konduksi dan konveksi pada baterai

3. Panas konduksi pada baterai kebanyakan terjadi secara radial dengan konduktivitas cukup tinggi sehingga perbedaan temperatur dari tengah ke pinggir baterai hanya sedikit. Besarnya laju panas konduksi pada baterai bisa didekati dengan rumus Fourier yang diadaptasikan ke bangun silinder sehingga membentuk persamaan: $Q=$ $2 \pi L k \frac{\left(T_{1}-T_{2}\right)}{\ln \left(\frac{r_{2}}{r_{1}}\right)}$

4. Laju perpindahan panas q" membesar ketika beban keluaran makin kecil. Hal ini disebabkan karena jika beban keluaran semakin kecil, arus keluaran yang dihasilkan semakin besar sehingga membuat Joule Heating makin besar. Pada penelitian ini rentang laju perpindahan panas pada baterai dengan beban $0.4-1.5 \mathrm{ohm}$ adalah $1.61-8.04$ $\mathrm{W} / \mathrm{m}^{2}$.

5. Melakukan simulasi panas baterai dengan software ANSYS Fluent cukup bisa mencerminkan hasil panas yang diperoleh pada praktek sesungguhnya, Data validasi menunjukan nilai error tertinggi sebesar $6 \%$.

\section{DAFTAR PUSTAKA}

Angelo, Onorati., and Cannova, Marcello., 2009, Thermal Characerization of Ion Lithium Battery Cell, Thesis, Politecnica de Milano, Italy

Chen, S.C., Wan, C.C., and Wang, Y.Y., 2004, Thermal analysis of lithium-ion batteries, Journal of Power Sources, 140, 111-124

Lai,Yanqing., Du, Shuanglong et al., 2015, Insight into heat generation of lithium ion batteriesbased on the electrochemical-thermal model at high discharge rates, International Journal of Hydrogen Energy, 40, 13039 - 3049

Liu, Guangming., Ouyang, Minggao., Lu, Langguang., Jianqiu,Li., 2014, Analysis of the heat generation of lithium-ion battery during charging and discharging considering different influencing factors, Journal of Thermal Analysis and Calorimetry, 261718814.

Saito, Yoshiyasu., Shikano, Masahiro., and Kobayashi, Hironori., 2012, Heat generation behavior during charging and discharging of lithium-ion batteries after long-time storage, Journal of Power Sources, 244, 294-299

Wang, Zhenpo., Fan, Wentaou., and Liu, Peng., 2017, Simulation of Temperature Field of Lithium Battery Pack Based on Computational Fluid Dynamics, The 8th International Conference on Applied Energy - ICAE2016, Energy Procedia 105, 3339 - 3344

Zhang, Xiao Xuan., Kleinb, Reinhardt., Subbaramanb, Anantharaman., Chumakovb, Sergei., Lib, Xiaobai., Christensenb, Jake., Lindera, Christian., Kim, Sun Ung., 2018, Evaluation of convective heat transfer coefficient and specific heat capacity of a lithium-ion battery using infrared camera and lumped capacitance method, Journal of Power Sources, 412, 552-558 